\title{
Homoseksuaalsuse sõnastamise katsed Eulenburgi skandaal ja Magnus Hirschfeld XX sajandi alguse Eesti ajakirjanduses
}

\author{
ANDREAS KALKUN
}

Tänapäevased identiteedikategooriad "heteroseksuaalsus” ja „homoseksuaalsus” on modernsed mõisted, mis kujunesid välja alles XIX sajandiks ning jõudsid aegamisi meditsiinidiskursusest tavakeelde. ${ }^{1}$ Eelmodernses eesti talupojakultuuris ilmselt polnud vajadust inimesi seksuaalse eelistuse järgi liigitada, mis muidugi ei tähenda, nagu oleks kogu ühiskond vaevata mahtunud heteronormatiivsesse mudelisse. ${ }^{2}$ Eestikeelse ühiskonna moderniseerumise protsessi ning euroopalikku mõtteruumi jõudmise käigus said siiski ühel hetkel ka siinmail tuntuks sõnad ja mõisted, millega oli Euroopas hakatud kategoriseerima inimesi vastavalt nende seksuaalsetele eelistustele heteroseksuaalseteks või homoseksuaalseteks.

Modernsete ideede levik ja uus maailmamõistmine sõltus tugevasti eestlaste lugemisoskusest ning ajakirjandusest kui laiadele massidele kõige kättesaadavamast värskest kirjasõnast. Sünnihetkest saadik oli eestikeelse ajakirjanduse üks funktsioone õpetamine ja silmaringi laiendamine. Lugejatele anti teada, mis laias maailmas sünnib ja mida sellest kõigest arvata. XIX sajandi lõpus ja eriti XX sajandi alguses muutus ajakirjanduse haare üha globaalsemaks ning õpetliku ja hariva kõrval sai järjest olulisemaks uudiseid vahendav ja meelelahutuslik funktsioon (Hennoste, Kurvits 2019: 21). Nii ajalehtede välimus kui ka sisu muutusid lihtsamini tarbitavaks ning üha kergema vaeva ja väiksema ajalise lõtkuga täitsid lehetegijad veerge ka põnevate välisuudistega. Järjest rohkem hakkasid eestikeelsetesse lehtedesse jõudma tõsiste maailmapoliitikast kõnelevate uudiste kõrval ka maailmas toimuvad skandaalsed kohtuasjad, hirmsad kuritööd ja veidrad juhtumid. Sajandivahetuse eestikeelne ajakirjandus tugines venekeelse kõrval üsna selgelt saksakeelsele meediaruumile. Saksakeelsed allikad ja eeskujud tähendasid aga seda, et Saksamaal toimuv või saksa lehtedes kajastatav jõudis küllalt sageli nii välisuudiste kui ka kõmu hulka. Vaatlen järgnevalt aastatel 1907-1909 Saksamaal toimunud kõmuliste kohtuprotsesside, nn

\footnotetext{
${ }^{1}$ Michael Foucault on oma „Seksuaalsuse ajaloos” püüdnud kaardistada seda hetke ajaloos, mil lihtsalt ühest pattulangenust teiste seas sai „homoseksuaal” kui eraldi „liik” (vt Foucault 2005: 50, 51). Vt ka kriitilist diskussiooni selle Foucault' kirjakoha üle nt Halperin 2002: 9, ka Taavetti 2018: 46.

${ }^{2}$ Jan Löfström on soome rahvaluule põhjal arvanud, et talupojakultuuris olid mehed ja naised mingis mõttes võrdsemad (kõik pidid tegema füüsilist tööd), nii et naiste ja meeste vahelise sümboolse erinevuse rõhutamine seksuaalsuse kaudu polnud relevantne, mis seletab ka näiteks homoseksuaalsust käsitleva folkloori vähesust (Löfström 1999, 2015: 133). Olen mujal arutanud eesti talupojakultuuris leiduva homoseksuaalsuse uurimise allikate ja võimaluste üle (Kalkun 2010a, 2010b, 2016, 2017, 2018).
} 
Eulenburgi skandaali ${ }^{3}$ peegeldusi Eesti ajakirjanduses. Kuna Eulenburgi protsessis esines tunnistajana homoseksuaalsuse dekriminaliseerimise eest võitleja ja seksuaalseid „kõrvalekaldeid” uuriv seksuoloog Magnus Hirschfeld (1868-1935), tutvustati Eulenburgi protsesside kajastustega seoses ka Hirschfeldi ideid. Kümnend hiljem külastas üleilmselt tuntud ja mainekas teadlane Hirschfeld Eestit ning pidas nii Tartus kui ka Tallinnas loenguid. Kuna prestiižsetes ja eesti rahvusega sümboolselt seotud paikades (Estonia ja Vanemuise teatrid) toimunud avalikud ettekanded leidsid ajakirjanduses rohket kajastamist, vaatlengi teise juhtumina Hirschfeldi loengute konteksti ja representatsioone ajakirjanduses.

Nii Eulenburgi skandaal kui ka Hirschfeldi külaskäigud sunnivad eestikeelset ajakirjandust sõnastama homoseksuaalset iha ning kontekstualiseerima seda lugeja jaoks. Mõlema juhtumi kajastused on ambivalentsed, ühelt poolt mõtestades homoseksuaalsust kui nähtust neutraalselt või seda pedagoogiliselt kontseptualiseerides, aga teisalt ilmutades ka homofoobiat ja eelarvamusi. Igal juhul on need varased sõnastamised märgilised, kuna tõstavad (meestevahelise) homoseksuaalsuse teemaks, mille üle on ühtäkki võimalik eestikeelses avalikus ruumis arutleda. Ajakirjandusel on olnud võim nimetada asju ning tõsta neid arutelu aineks ning sellega ilmselt muuta nii diskussiooni ruumi kui ka sisu. Kui uskuda, et keel loob kategooriad, mille abil me mõtleme oma seksuaalsest ihast, identiteedist ja praktikatest (vt Cameron, Kulick 2003: 19), siis on nimetamise diskursuse uurimine väga oluline. Järgnev püüabki esitada marginaalseid killukesi minevikust (kõmu-uudised ja populaarsed loengud ning nende rahvalikud kokkuvõtted), millel pole justkui Eesti üldajaloo jaoks mingit tähtsust, kuid mis on oma olemasoluga võinud mõjutada heteronormi mitte mahtuvate inimeste elu.

\section{Eulenburgi skandaali kajastused}

Eulenburgi skandaaliks kutsutakse aastatel 1907-1909 toimunud kõmulisi kohtuprotsesse, mis raputasid Saksa keisri Wilhelm II õukonda. Skandaal sai alguse, kui ajakirjanik Maximilian Harden vihjas oma ajalehes Die Zukunft keisri lähikondlaste Eulenburgi prints Philippi ja Kuno von Moltke homoseksuaalsusele. Hardenit olevat skandaalseks paljastuseks kannustanud hirm, et suures osas homoseksuaalsetest meestest koosnev nn Liebenbergi sõpruskond mõjutab liiga tugevalt Wilhelm II poliitilisi otsuseid ja on riigile kahjulik. Juba 1906. aastal avaldas Harden oma lehes karikatuuri mõistatusliku dialoogiga, kus Harfimängija (sks Harfenspieler) ja Kallike (Schätzchen) rääkisid rünnakutest Liebenbergi sõpruskonna pihta ning kasutasid Wilhelm II kohta sõna Armsake (Liebchen). Mõistujutt ja pilt olevat tekitanud nii kõrgetes sõjaväeringkondades kui ka lehelugejate hulgas kuulujutte ja sahinat, aga ka paanikat. 1907. aasta 27. aprilli lehes paljastas Harden, et Harfimängija kujutas Eulenburgi prints Philippi ja tema Kallike kindral Kuno von Moltket. Samas artiklis

\footnotetext{
${ }^{3}$ Nimetatud ka Liebenbergi afääriks (nt Mancini 2010) või Harden-Eulenburgi afääriks (nt Vērdiņš 2016).
} 
oli mainitud veel mõnda riigivõimule lähedal seisvat homoseksuaalset meest, nagu riigikantsler Bernhard von Bülow jt (vt lähemalt Domeier 2015b).

Kirjutise tõttu kaebas kindral Kuno von Moltke Maximilian Hardeni au ja väärikuse solvamise eest kohtusse. Tunnistajana esines protsessil muuhulgas Moltke lahutatud naine Lilly von Elbe, kes kirjeldas kohtus avameelselt oma pikantset ja mittetoimivat abielu homoseksuaalse mehega. Eksperthinnangu Moltke seksuaalsele sättumusele andis kohtu ees ka seksuoloog Magnus Hirschfeld. Kaalukate ja skandaalsete tunnistuste tõttu võitis protsessi Harden, kuid see kohtuasi oli alles avalöök järgnevale. ${ }^{4}$ Protsessil oli tunnistajana esinenud muuhulgas Eulenburgi prints Philipp, kes eitas vande all enda ja Moltke homoseksuaalsust. See detail andis võimaluse süüdistada printsi valevandumises, sest Harden oli leidnud Baierimaalt kalamehe, kes oli valmis kohtus avalikult tunnistama, et ta oli noore mehena olnud printsiga homoseksuaalses vahekorras (Domeier 2015b: 183). Tähelepanuväärselt ei süüdistatud nendes kohtuasjades kedagi siiski Saksa karistusseadustikus homoseksuaalsust kriminaliseeriva $\$ 175$ alusel, kuna kõrgklassi ja avaliku elu tegelasi puudutavate avalike protsesside puhul oli ilmselt kõigile mugavam, kui sellest paragrahvist sai kuidagi mööda vaadata (vt Domeier 2015b: 110). Vastastikused süüdistused ja protsessid jätkusid 1909. aastani, ning osapooled said tunda nii ajutisi võite kui ka kaotusi. Protsessidel osalejaid tabasid ridamisi tervisehädad, protsesse lükati edasi ning avalikkuse pidev negatiivne tähelepanu sundis mõnda püsivalt eksiili jääma.

Kõiki protsesse saatis erakordne avalik huvi ning neist kohtuasjadest ongi kõneldud kui uut tüüpi rahvusvahelisest meediasündmusest, kus poliitika performatiivne loomus ja ajakirjanike kommertshuvidest tingitud kõmujanu sünnitasid enneolematu skandaali (Domeier 2015b: 9). Eulenburgi juhtum oli esimene XX sajandi homoseksuaalne skandaal, kus intiimsest loost ja Saksamaa siseasjast sai kogu maailmale huvi pakkuv sündmus. Modernne ajakirjandus oli järjest enam seotud meelelahutusega ning pikantsed lood ja kollased uudised olid väljaannetele ka majanduslikult järjest olulisemad.

Kui veel 1895. aastal Londonis toimunud kõmuline kohtuasi, kus Oscar Wilde’i süüdistati homoseksuaalsuses, tolleaegsetesse eestikeelsetesse lehtedesse ei jõudnud, ${ }^{5}$ siis XX sajandi algul kogu maailma erutanud Eulenburgi skandaal leidis kiiresti tee ka eestikeelse lugejani. Nii kohalikud kui laiema levikuga lehed kajastasid sündmusi,

\footnotetext{
${ }^{4}$ Järgmises kohtuinstantsis kaotas Harden, kuna Lilly von Elbe kuulutati hüsteerikuks ja tema tunnistustel polnud enam kaalu. Samuti oli Hirschfeld loobunud oma varasematest eksperthinnangutest. Eulenburgi skandaaliga on seotud ka 1907. aastal toimunud kohtuprotsess, kus esimese saksakeelse homoseksuaalse ajakirja Der Eigene toimetajat Adolf Brandi süüdistati kantsler Bernhard von Bülowi homoseksuaalseks laimamises.

${ }^{5}$ Oscar Wilde’i kohtuasja mainitakse Postimehes alles seoses homoseksuaalse töösturi Alfred Kruppi surmaga 1902. aastal (nime vigane ortograafia viitab, et ei kirjutaja ega toimetajad pole Wilde'iga kuigi tuttavad): „Arstid ütlevad, et inimesi, kellel sarnased vead on, arstitama peab, aga mitu kord ei ole teie juba juhtumiste üle lugenud, kus vähem rikkaid ja mõjukaid inimesi sarnaste kuritööde eest raskesti karistati! Näituseks õnnetu anderikas kirjanik Wald, kelle kurbmäng alles nende päevade sees Münchenis ja Berlinis suurt kiitust leidis. Sellesama süü eest, milles Kruppi süüdistati, mõisteti ta Londonis sunnitööle." (Politika ringvaatus 1902b) Põhjalikum käsitlus Wilde’i elust ja vangistamisest „,vastuloomulise kombe” pärast esitatakse eestikeelses ajakirjanduses alles 1920. aastal (Hunntus 1920).
} 
ülevaateid protsessidest leidus nii konservatiivsetes ja kristlikes kui liberaalsetes lehtedes. ${ }^{6}$ Vahendati kohtuasjades kõlanud tunnistajate ütlusi, aga püüti lugejale seletada ka sündmuse laiemat maailmapoliitilist või moraaliõpetuslikku konteksti. Tähelepanuväärselt pidid ajakirjanikud lugejale sõnastama asju, millest seni eestikeelsetes lehtedes kirjutatud polnud. Kuidas kajastati eestikeelsetes lehtedes kohtus arutatud intiimset seksuaalelu ja homoseksuaalsust puudutavat? Lehetegijad väljendasidki sealjuures sageli lugejale oma kimbatust ning kirjutasid sellest, kui sõnulseletamatult, mustad, inetud, imalad, läilad, hapud ja jäledad on kohtukulli ees arutatud detailid. Sageli eelnebki pikantsete detailide esitamisele nending, et tegelikult pole võimalik ega kohane järgnevast kõnelda.

Saksamaa ajalehed kirjutavad nüüd pikalt ja laialt ühest kõmuprotsessist, mis Berlinis praegu ajakirjaniku Hardeni ja endise Berlini komandandi krahv Moltke vahel käsil on. Lool on üleüldine tähtsus, kuid ta on nii inetu kuju saanud, et häda ja hale rääkida. (Väljamaalt 1907a)

Siin pole muidugi paik neid jäledaid tegusi harutama hakata, tähendame ainult nii palju, et soldatid tihtilugu kaebtust tõstnud, et nende ülemad nendega liiga armsalt ümber käia tahavad ja et need ülemad iseäraliseks seltskonnaks, terveks politikaliseks erakonnaks kokku astusivad ja kõiki kõrgemaid ametikohtasi riigis oma kätte püüdsivad saada, ühes sellega Saksamaa sisemise politika peale mõjudes. (Väljamaalt 1907b)

Ja selle kohta tuli otse inetuid asju kuuldavale. Väga läila on juba see, mis avalikul kohtu pidamisel ette tuli, kuid osalt tunnistusi anti kinniste uste taga, ja seal seletatud asju, mida avaldada võimata on. (Politika ringvaade 1907b)

Nii nagu Saksamaal nähti skandaali ülemaailmses laialdases kajastamises ohtu saksa rahvusele, perekonnainstitutsioonile ja üldisele moraalile (vt Domeier 2015b: 5), muretsesid ka kohtuasju käsitlenud eestikeelsed ajalehed silmakirjalikult, mida võiks küll tähendada, et inimesed sellise „haiseva loo” järjekordseid kajastusi nii suure isuga ootavad.

Kohtu-arutamine läks viimati nii läilaks, et otsustati seda osalt kinniste uste taha teha. Kuid palju abi ei olnud sellestgi, sest ajalehed kirjutavad ometi asjast pikalt ja laialt. Kõik see asi näitab kohutava selgusega, kui mädanenud ja raisus olud paljudes kõrgemates ringkondades on. Teiselt poolt aga sigitab see nähtus muret, et inimesed sarnase haiseva loo arutusi nii otsata isuga kuulda ja teada tahavad ning selle kõdistamisetungi täitmiseks ajalehed oma veergusid protsessi käiguga täidavad. Kurdetakse, et Saksa rahva kõlblik terveks saamine küll muidu ei tule, kui mõne hirmsa raputuse mõjul. (Politika ringvaade 1907a)

\footnotetext{
${ }^{6}$ Skandaal jõudis näiteks ka Vene impeeriumi lätikeelsetesse lehtedesse, skandaali kajastustest Lätis on kirjutanud Kārlis Vērdiṇš (2016).
} 
Siiski kajastati sündmusi nende toimumise ajal üllatavagi põhjalikkusega ega tehtud lugeja ees saladust, et lugu on skandaalne ja võiks huvi pakkuda. Protsessi kirjeldusi võidi alustada iseloomustusega, mis vihjas otsesõnu põnevusele, näiteks: „Ülekuulamine oli otse dramaatiliselt põrutav” (Vürst Eulenburgi... 1908). Eulenburgi skandaal kestis pikka aega ning seetõttu olid ka ajakirjanike kirjutised seriaalse ülesehitusega. Kirjutiste alguses seoti lugu varem avaldatud tekstidega või tehti lühike kokkuvõte senisest asjade käigust, näiteks: „Minevases numbris kirjeldatud suures kõmu protsessis on nüüd otsus antud” (Politika ringvaade 1907b) või „Nagu minevases numbris nimetasime, peeti Saksamaal mineval nädalal teist seda maiku protsessi, kui nädal varem suure kõmuline Hardeni protses oli” (Politika ringvaade 1907c). Artikli kokkuvõttes lubati, et veelgi põnevam järg on tulemas, ning seoti lugeja sedasi edaspidi ilmuvate tekstidega: „Tõdetakse suuri ilmutusi” (Väljamaalt 1908) või „Küllap edaspidi kuuleme” (Politika ringvaade 1907c). Mahlaka loona soojendati ajakirjanduses Eulenburgi skandaal ka aastaid hiljem üles, nii et detailseid kokkuvõtteid sai eesti lugeja sellest lugeda näiteks veel 1915. aastal Uuslehest (Järjejutt 1915) ja 1929. aastal Rahvalehest (Nende elu... 1929).

Vaatamata Eulenburgi skandaali kajastustega kaasas käinud kahtlustele ning sõnastamisraskustele jagati siiski lugejaga kohtusaalist Saksamaa kollase ajakirjanduse kaudu väljaimbunut. Paljudel juhtudel püüti homoseksuaalset vahekorda mitte nimetada ja kasutati ümberütlevaid väljendeid, nagu kõlvatumaid tegusid ette võtma meesterahvaste juures, või mitmetähenduslikke eufemisme: ühes olema, sarnaseid asju tegema. Homoseksuaalsete meeste kohta võidi kirjutistes öelda umbmääraselt niisuguse kire tagaajaja, säherdusel viisil patustaja inimene ning homoseksuaalsusestki võidi kirjutada väga üldiselt kui hirmsast patust, vaimumustusest või inetust kõlblusevastasest elust.

Meie teatasime juba eila sellest asjast, mis Saksamaal ja kogu ilmas nüüdsel ajal lõpmata palju tolmu teeb ja suurte meeste kodust elu lõpmata mustalt ja poriselt ilmale näitab. Täna toome lühidalt teateid 11. oktobri ülekuulamisest. Kui tunnistajale B., endine kürassir, krahv Eulenburgi pilti näidati, kas ta seda herrat tunneb, ütles mees, et see herra ka olla Lynari juures märatsemise pidul olnud, kus meesterahvaste juures kõlvatumaid tegusi ette võetud. (Moltke-Hardeni... 1907)

Et lugeja selliste segaste väljenduste tõttu asjadest valesti aru ei saaks, peab näiteks kristlik ajaleht vajalikuks lisada viite Pauluse kirjale roomlastele ( $\mathrm{Rm} 1: 27)$, et oleks üheselt mõistetav, millele osutab kohmakas homoseksuaalsuse ümberütlus „haiglase meeleoluga inimesed, kelle sugulik tundmus korras ei ole" (Väljamaalt 1907a). Sõna homoseksuaalsus (kujul homoseksualismus) oli tolleaegse tavalise lugeja jaoks ilmselt liiga võõras, nii ongi seda kasutatud vaid paaris Eulenburgi skandaali käsitlevas tekstis. ${ }^{7}$ Homoseksuaalset suguühet tähistatakse kõige sagedamini väljenditega, mis rõhutavad selle praktika loomuvastasust: loomuvastane vahekord, loomuvastane

\footnotetext{
${ }^{7}$ Dan Healey väidab, et sõna homoseksuaalsus võeti Vene impeeriumis küllaltki hilja kasutusele. Keskmine haritud venelane olevat 1895 . aastal vene keelde jõudnud sõna hakanud kasutama alles pärast 1905. aastat (vt Healey 2001a: 11).
} 
suguline läbikäimine, loomuvastane himude täitmine, loomuvastane suguline kõlvatus, loomuvastane suguline kokkuelamine, loomuvastalised tunded, loomuvastase kirgede täitmise toimetamine meesterahvastega, suguvastane kõlvatus, suguliselt mitte loomulikud herrad, kõlblusvastane vahekord, looduse-vastane „meestearmastus” ja seaduseja kombevastane ühendus. Harvem leidus neutraalseid formuleeringuid, nagu meeste armastus, meesterahvaste omavaheline sugulik löbutsemine. Selline väljendite rohkus viitab olukorrale, kus üldiselt kasutatavat ja mõistetavat terminit pole olemas. Niisiis on kirjutajad pidanud iga kord mõiste uuesti sõnastama. Kohati leidubki kirjutistes pikki ja kohmakaid eufemistlike ümberütlemiste sarju, nagu järgmises näites.

Kohtu otsuses on öeldud, et krahv Moltke teguviisis ja olekus küll midagi nuhtluse väärilist pole leitud, kuid selgeks olla ometi saanud, et tema suguelulik tundmus võõriti teel ennast on avaldanud, et temal naisterahva sugu kohta vastik tundmus olnud, aga meeste sugu vastu liig õrnus. Sellepärast ei võida Hardeni kirjutusi mitte teotamiseks pidada, ega teda selle eest nuhelda. (Politika ringvaade 1908)

Kuigi eestikeelsetes ajalehtedes avaldatud kirjutised Eulenburgi skandaali kohta on suures osas referatiivsed ja toetuvad Saksa allikatele, on ajakirjanikud siiski pidanud neis kokkuvõtteis ka mingeid omi seisukohti avaldama. Kuna läbivaks teemaks on homoseksuaalsus, on siin võimalik tutvustada eesti lugejale tol ajal Saksamaal toimunud diskussioone selle üle, kas homoseksuaalsus pole mitte kaasasündinud omadus ning kas sel juhul ikka peaks riik sellise sättumusega inimesi karistama. Näiteks seletades lugejale Eulenburgi skandaaliga seotud ajakirjanik Adolf Brandi ja kantsler Bernhard von Bülowi kohtuasja kulgu, tutvustab ajakirjanik põhjalikult Saksamaal toimuvaid homoseksuaalsuse dekriminaliseerimise arutelusid ja tausta.

Brandil aga ei olnud oma jutuga küll muud otstarbet kui kõmu teha. Ning tema kirjutus oligi ka üsna teistsugune. Ta ei arvanudgi sugugi sarnast looduse-vastast „meestearmastust”, mida Harden suurnikkudele raskelt ette heitis, mingiks süüks, vaid kirjutas oma lendlehe otse selleks, et Saksa riigi nuhtluseseadusest see paragrahv (175), kus nimetatud tegu süüvääriliseks arvatakse ja sellele nuhtlus määratakse, ära kaotatakse. Sest meesterahvaste omavaheline sugulik lõbutsemine ei olla sugugi loomuvastane.

Seda on Saksamaa „peenikesed” ringkonnad juba ammu nõudnud, nad ütlevad prg 175 ilmaaegu inimese vabaduse takistaja olema, sest mis inimene oma enese keha juures teeb ehk talitab, ei puutuda kellegile teisele. Iseäranis elav oli see kaotusenõue mõne aasta eest, kui kuulsale miljonärile Kruppile ta niisugust teguviisi ette heideti, mille pahanduse kätte mees surigi. ${ }^{8}$ Kuid valitsuse piirides ei tahetud kaotamisest

\footnotetext{
${ }^{8}$ Friedrich Alfred Krupp (1854-1902) oli suurtööstur, kes suri või tegi enesetapu pärast seda, kui Itaalia ajalehtedest jõudsid Saksamaa lehtedesse kuuldused tema homoseksuaalsest elust Capri saarel. Eesti lehtede seas annab Olevik väga põhjaliku ülevaate Kruppi skandaalist, kuid mainib vaid umbmääraselt, et tema kuritegu käis paragrahv 175 alla, seletamata lugejale lahti, millist kuritegu see tähendab (kõneldakse umbmääraselt haisvast mudast, liiderlikust elust, häbi- ja kuritöödest) (Väljamaa 1902b, vt ka Väljamaa 1902a). Postimees annab lugejale esmalt moondunud infot ja kirjutab, et Itaalia leht olevat Kruppi süüdistanud kümne alaealise tüdruku äraeksitamises (Politika ringvaatus 1902a). Hiljem tõmmatakse paralleel Oscar Wilde’i juhtumiga ning vihja-
} 
kuulda. Brand püüdis oma lendlehes siis riigi kantsleri Bülowi torkida, umbes selles mõttes, et see „sööb ja salgab”. Bülow oli nimelt ühe oma sooja sõbra Scheeferi seltsis suvitama sõitnud ja temaga seal kaua „ühes olnud”. Loost kirjutades tarvitas Brand veel iseäralist Saksakeelset sõnamängu. Ta kõneles „Scheeferi tunnikestest”, mis Saksakeeles õrna armatsemist, kudrutamist, või umbes selle sarnast tähendab. Mees lootis nii ääri-veeri mööda rääkimisega end küll hädakorral mõne tagaukse kaudu välja poetada. Mõne teise juures oleks see vahest korda läinud, kuid riigikantsleriga polnud nalja. Brandi kirjal käis kähku kohus ja karistus kannul. Küll oli teine omale terve tosina täisverelisi suurnikkusid tunnistama tellinud, ühe vürsti ja mitu krahvi, mitmed nendest Hardeni loost tuttavad (nimelt Lynar). Kuid need tunnistasivad muidugi seda mis tahtsivad. Hardengi oli tunnistajaks. Kuid ta ei teadnud ühtegi Brandi heaks ütelda, ja nii tuli siis kohtu otsus kuri: Brand pandakse poolteiseks aastaks vangi. (Politika ringvaade 1907c)

Kuna Eulenburgi skandaalis osalenud homoseksuaalsed mehed olid kõrgemast seisusest, vihjavad ka eesti ajakirjanikud, nagu oleks homoseksuaalsus kui nähtus seotud just kõrgklassiga. ${ }^{9}$ Kasutataksegi termineid, nagu suurte herrade eralõbu ja peenikese seltskonna liikmed. Samas leidub ka empaatilisi kirjutisi, mis tunnevad kaasa kõrgest seisusest meeste langusele. „Jah, auukõrgusest naeruväärilise olekuni on ainult üks samm!” nendib Kaja ajakirjanik, olles teinud kokkuvõtte prints Eulenburgi elukäigust (Politika ringvaade 1908). Kõrgest seisusest inimestelt näikse oodatavat ka kõrgemat moraali, et alamad kihid nende eeskujul eksiteele ei satuks. Eesti ajakirjanikud seovadki Eulenburgi kohtuasjadega sündinud moraalipaanika huvitaval kombel klassiküsimusega: ${ }^{10}$ „Ka teisigi asju on viimasel ajal sündinud, mis selgusega näitavad, kui halb see on, „kui sool tuimaks läheb”, kui „suurtsugu inimesed” alamatele kihtidele näitavad, kuda mitte ei pea elatama” (Politika ringvaade 1907a).

Eulenburgi skandaal oli tähtis verstapost globaalses homoseksuaalsuse ajaloos, kuna tegi ühtäkki võimalikuks nähtuse avaliku arutamise. Diskussioon Eulenburgi printsi ja Kuno von Moltke võimaliku homoseksuaalsuse üle muutis juba pelgalt avalikus meedias toimunud verbaliseerimisaktiga seda, kuidas homoseksuaalsust sai käsitleda. Ühtlasi on Eulenburgi skandaali muidugi peetud ka moodsa homofoobia sünnihetkeks (vt Domeier 2015a: 13). Ka Eesti lugejale maalitakse muuhulgas homofoobne pilt homoseksuaalide kuritegelikust ringist, kelle salajased kombitsad ulatu-

takse, et Wilde’i karistati sellesama süü eest, milles Kruppi süüdistati. Kirjutatakse, et sarnaste vigadega inimesi peaks arstima, kuid ka kahjutuks tegema (Politika ringvaatus 1902b). Ka Uus Aeg kõneleb umbmääraselt Kruppi haiguslisest kombevastasest tegevusest (Väljamaalt 1902). Ristirahva Pühapäevaleht kirjutab eufemistlikult või õndsas teadmatuses, et Kruppi süüdistasid sotsialistlikud ajalehed kuuenda käsu rikkumises (Maailma riikidest 1902).

${ }^{9}$ Ka eesti rahvaluules on olemas motiiv, kus heteronormist erinevat seksi seotakse kõrgemate klassidega. Näiteks regilauludes sisalduvad vihjed sodoomiale on funktsioneerinud sõimuna mõne kõrgema ühiskonnaklassi (kubjas, saks) stigmatiseerimiseks (Kalkun, Sarv 2014: 105106).

${ }^{10}$ Kārlis Vērdiṇši järgi prevaleeris Eulenburgi skandaali lätikeelses käsitluses ja selle järelkajades just varjamatu saksavaenulik ideoloogia, st rõhutati just saksa rahvuse „perversseid” ihasid, vt Vērdiņš 2016: 128 jj. 
vad kõikjale ning kes ohustab Wilhelm II riiki ja laiemalt kogu ühiskonda. Samas vahendatakse aga ka uudset ideed, et homoseksuaalsus on meditsiiniline nähtus ja seega ei peaks selle eest inimesi karistama. ${ }^{11}$

\section{Eesti lehelugeja esimesed kokkupuuted Magnus Hirschfeldiga}

Pärast kurikuulsat Oscar Wilde’i kohtuasja olevat saksa arst ja seksuoloog Magnus Hirschfeld tundnud tungivat vajadust võidelda selle eest, et homoseksuaalsus poleks asi, mille eest inimesi karistatakse (vt Bauer 2017: 52; Mancini 2010: 18). Hirschfeld asutaski 1897. aastal koos kirjastaja Max Spohri ja teistega Teaduslik-humanitaarseks komiteeks (Wissenschaftlich-humanitäre Komitee) nimetatud organisatsiooni, mille põhieesmärgiks oli võidelda homoseksuaalsuse dekriminaliseerimise eest Saksamaal, aga ka laiemalt kogu maailmas. Anakronistlikult võiks öelda, et tegu oli esimese LGBTI inimeste õiguste eest võitleva organisatsiooniga Euroopas. Koguti allkirju petitsioonidele, korraldati rahvusvahelisi kongresse ja propageeriti modernse arstiteaduse uusi seisukohti heteronormist erinevate inimeste kohta. 1919. aastal avas Hirschfeld Berliinis seksuaalteaduste instituudi (Institut für Sexualwissenschaft), mille eesmärk oli edendada inimese seksuaalsuse uurimist ning anda seksuaalharidust (vt Mancini 2010). Hirschfeld oli viljakas kirjutaja, ning ühes oma peateoses „Die Homosexualität des Mannes und des Weibes” („Mehe ja naise homoseksuaalsus", 1914) oli Hirschfeld maininud, et Liivi- ja Kuramaa aadliperedes on väga palju tõelisi homoseksuaale (sehr viel echte Homosexuelle) ning suuremates linnades, nagu Riias, Liepājas, Jelgavas ja Tallinnas, olevat homoseksuaalide kohtumispaiku, mis polevat küll väga rahvarohked. Hirschfeldi väitel leiduvat Riias ka homoseksuaalsetele meestele mõeldud prostituute (vt Veispak 1991: 106; Hirschfeld 1920).

Teaduslik-humanitaarse komitee valgustustegevuse raames pidas Hirschfeld kogu Euroopas ettekandeid ja loenguid. Loengud ei puudutanud ainult homoseksuaalsuse teemat, vaid näiteks ka naiste õiguste küsimusi, abordivabadust ja karskusteemat. Eestikeelses ajakirjanduseski mainitakse Hirschfeldi esmakordselt seoses Viinis peetud ülemaailmse karskuskonverentsiga, kus ta 1901. aastal esines (Kaheksas rahvusvaheline... 1901). Eesti lehelugeja lähem tutvus Hirschfeldiga toimub aga Eulenburgi skandaaliga seoses. Nii saab selle poliitilise homoskandaali kajastustest omamoodi sissejuhatus Hirschfeldi 1920. aastate lõpus Eestis toimunud loengutele.

Eulenburgi skandaali esimeses kohtuasjas, kus Berliini kuberner kindral Kuno von Moltke süüdistas ajakirjanik Hardenit auhaavamises, pidi süüdistatav tõestama, et ta pole valet rääkinud, kui nimetas Moltket homoseksuaalseks. Selleks tõid mõlemad osapooled kohtusaali oma eksperdid, kes pidid andma hinnangu Kuno von Moltke seksuaalsusele. Kuna küsimus ei olnud homoseksuaalsuse paragrahvis 175, mille puhul süüdistus põhines tavaliselt faktil, et on toimunud meestevaheline

${ }^{11}$ Kārlis Vērdinš̌ toob näiteid, kuidas Eulenburgi skandaali lätikeelsetes käsitlustes kommenteerisid ajakirjanikud selliseid uudseid seisukohti homofoobsel viisil (Vērdiṇš 2016: 127). Eesti kajastustes vahendatakse selliseid mõtteid suhteliselt neutraalselt. 
suguühe, ${ }^{12}$ pidid eksperdid lihtsalt andma hinnangu, kas Moltke on potentsiaalselt homoseksuaalne, mitte tõestama, et ta on olnud homoseksuaalses vahekorras. Siin oli tuleviku seisukohast oluline aspekt, et seega justkui vaikimisi nõustuti moodsa teooriaga, et homoseksuaalsus on kaasasündinud. Sealjuures usuti, et homoseksuaalset inimest oleks nagu mingite objektiivsete tunnuste abil võimalik tuvastada ka juhul, kui inimene pole kunagi homoseksuaalses vahekorras olnud (vt ka Domeier 2015b: 113).

Mõlemad eksperdid, nii Hirschfeld kui Moltkede perekonnaarst, suguhaigusi uurinud Georg Merzbach, kuulusid iseenesest homoseksuaalsete inimeste õiguste eest võitlejate hulka ja olid ka Teaduslik-humanitaarse komitee liikmed, st taotlesid homoseksuaalsuse dekriminaliseerimist. Siiski läksid nende hinnangud Moltke osas lahku. Hirschfeld esitas kohtusaalis ekspertarvamuse, et Moltke on homoseksuaalne, st Hardeni kirjutatu on tõsi. Hirschfeld, kes soovis homoseksuaalsuse legaliseerimist, olevat uskunud, et tõendades kõrge sõjaväelase Moltke homoseksuaalsust, aitab ta sellele kaasa. Ta tunnistas, et Moltke on normaalne, kuid kaasasündinult homoseksuaalne, aga rõhutas, et homoseksuaalsus võib olla potentsiaalne või „platooniline”, st pole alust arvata, et Moltke oleks homoseksuaalsust praktiseerinud (vt Domeier 2015b: 113). Eesti lehed vahendasid Hirschfeldi etteastet lugejatele järgneval moel.

Asjatundja Dr. Hirschfeld leiab, et Moltkel kõik niisugused märgid olemas on, nagu nad säherdusel viisil patustaja inimese juures nähtavale tulevad. Nüüd on juba täitsa avalikuks tulnud, et Moltke meestesugust isikutega seaduse- ja kombevastases ühenduses on seisnud.

Teine asjatundja, Dr. Mertzbach, salgab esimese asjatundja poolt antud tõenduse ülemal nimetatud märkide kohta ära ja ütleb, et krahv Moltke täitsa terve, normal inimene olla.

Tunnistaja, major Balsen, kinnitab, et Eulenburgi kohta avalikult sellest patustamisest kõneldi. (Moltke-Hardeni... 1907)

Esimene kohtuinstants otsustas, et Merzbachi hinnang, nagu Moltke poleks homoseksuaalne ning kõik vastaspoole argumendid viitaksid lihtsalt meestevahelisele lähedasele sõprusele, ei ole objektiivne (Domeier 2015b: 117).

Pärast Eulenburgi skandaali võiski Hirschfeldi nime Eesti lehtedes leida seoses vahendatud Saksamaa kõmu-uudistega, kus seksuoloog taas andis kohtusaalis oma eksperthinnangu mitmesuguste skandaalsete (seksuaal)kuritegude kohta.

\footnotetext{
${ }^{12}$ Selle tõestamiseks toimus harilikult arstlik läbivaatus, mis oligi tol ajal homoseksuaalse vahekorra tõestamisel tavaline kohtulik praktika, vt Domeier 2015b: 112.
} 


\section{Magnus Hirschfeldi loengud ja nende kajastused}

See, et maailmakuulus seksuoloog ja homoseksuaalsuse dekriminaliseerimise eest võitleja Hirschfeld käis Tartus ja Tallinnas loenguid pidamas, polnud kindlasti juhuslik. Hirschfeldi kontaktisik Eestis oli tõenäoliselt Alexander Lipschütz ${ }^{13}$, kes oli aastatel 1919-1926 Tartu ülikoolis füsioloogia ja füsioloogilise keemia professor. Lipschützi tööd seksuaalse endokrinoloogia alal olevat pakkunud Hirschfeldile suurt huvi (Healey 2001a: 134). 1921. aastal osales Lipschütz Berliinis Hirschfeldi organiseeritud esimesel ülemaailmsel seksuaalreformi konverentsil ettekandega „Die innere Sekretion der Geschlechtsdrüsen und ihre Bedeutung des endokrinen Systems für die Sexualität” („Sugunäärmete sisesekretsioon ja selle tähendus seksuaalsuse endokrinoloogilise süsteemi jaoks") ning sellest andsid teada ka Eesti lehed.

Berliinis peetakse 15.-19. sept. Virchow-Langenbecki majas ja sexualteaduse instituudis rahvusvaheline sexualreformi kongress ära, millest kuulu järel ka Tartu ülikool osa võtab. Kongressi korraldajateks on nende küsimuste eriteadlane, kuulus Dr. Magnus Hirschfeld, tuntud naisõiguste eestvõitleja Dr. Helene Stöcker, Inglise teadusemees Havelock Ellis ja Tartu professor Dr. Al. Lipschütz. Viimane on sellel alal oma teadusliste uurimiste ja katsete läbi Tartu Ülikooli füsioloogia instituudis laialise tutvuse omandanud. Tema raamat: „Über die innere Sekretion der Geschlechtsdrüsen” (= sugunär̈rmete sisemise immitsemise üle), on sexualteaduse ilmas suurt tähelepanu leidnud. Selle tutvuse tõttu ongi siis professor Lipschütz üheks peaettekandjaks kutsutud ühes Praaga ülikooli professor Biedl'iga. Nõnda on Tartu ülikoolil hea juhus teaduseilmale oma olemasolust ja uurimistööde ning teaduslikkudest katsetest tunnistust anda. (Ülikooli teated 1921)

Kongressil osales Tartust veel professor Ludvig Puusepp, kes pidas ettekande teemal „Der Blutkreislauf im Gehirn beim Koitus” („Vereringe ajus suguühte ajal”) (vt ettekannete publikatsioone Weil 1922).

Hirschfeld käis Eestis ja pidas loenguid vähemalt kahel aastal (1928 ja 1929). Mõnest avalikust loengust ilmusid ajakirjanduses küllaltki põhjalikud referaadid, teistest teame ainult ajalehes ilmunud reklaamide või loengus osalenute kirjutistes leiduvate vihjete kaudu. Eestis toimunud ettekanded olid ilmselt osa Hirschfeldi suurematest ringsõitudest. Näiteks andsid ajalehed teada, et Eestis peetud loengutele eelnesid ettekanded Riias ning järgnesid Skandinaavia või Nõukogude Liidu külastused.

\footnotetext{
${ }^{13}$ Alexander Lipschütz (1883-1980), füsioloog, endokrinoloog ja antropoloog. Riias sündinud Lipschützi Tartusse professoriks kutsumise eel tutvustas Päevaleht teda kui „sündimise poolest baltimaalast”, kes rääkivat väga hästi saksa ja vene keelt, on Šveitsi Sotsiaaldemokraatliku Tööliste Partei liige, olevat aidanud „,viimasel ajal nii teo kui ka nõuga Eesti vabastamise püüetele kaasa" (Prof. A. Lipschütz... 1919, vt ka Seltsimees Prof... 1919). Lipschütz on ajakirjanduse andmeil olnud aktiivne loengupidaja (nt karskus- ja õpetajate konverentsid ning muud avalikud esinemised), mõned populariseerivate loengute referaadid ja kokkuvõtted on ka avaldatud (vt Lipschütz 1921, 1923).
} 
1926. aasta 18. mail pidas Hirschfeld loengu Riias (Lipša 2016: 149) ning lektorit tutvustati kui „kuulsat homoseksualismi spetsialisti”. Loengus esitas ta muuhulgas seisukoha, et riik ei peaks sekkuma kahe osapoole nõusolekul toimunud homoseksuaalsetesse aktidesse ega karistama inimesi nende sünnipärase loomuse pärast (Lipša 2018: 20). Eesti ajalehtedes ilmunud referaadis nopiti Riias toimunud loengust välja seekord vaid abordiõigust puudutavad seisukohad ega pööratud seksuaalsuse teemale tähelepanu.

Üleilma kuulus seksoloogia professor Magnus Hirschfeld pidas mõne päeva eest Riias käsitööliste seltsi saalis huvitava teadusliku kõne, milles tähendas abortide kohta, et tema on olnud aastakümned abortide vastu, nõudes valju karistusi suguvilja hävitajatele, kuid tutvunedes rohkem tegeliku eluga ja sotsiaalse viletsusega ei ole saanud ta teisiti, kui pidanud vaadet muutma. „Kui kõrge karistuse hirmust hoolimata”, kõneles prof. Hirschfeld, „on Saksamaal iga aasta 800.000 aborti, kuid kohtuliku karistuse alla langeb ainult kuni 300 naisterahvast. Ja need, kes karistuse alla langevad, on kõige vaesemad, kõige abitumad, kõige kavalusetumad. Niisugune seisukord on juba väljakannatamata. Olin kodanlane, kuid pidin pooldama abordi küsimuses pahempoolseid". Professor arvab, et tuleks igas riigis maksma panna niisugune seadus, kui on Nõukogude Venes, mis annab abortide tegemiseks vabaduse. Abortide rohkuse põhjuseks arvab prof. Hirschfeld raskeid sotsiaalseid tingimusi pärast sõda. (Prof. M. Hirschfeld 1926a) $)^{14}$

Vahetult pärast Riia külastust, 1926. aasta juunis külastas Hirschfeld ka Nõukogude Liitu, kus pidas tervishoiu rahvakomissari Nikolai Semaško kutsel loengu. Kuigi Nõukogude Liidus ei olnud selleks ajaks homoseksuaalseid suhteid veel kriminaliseeritud ${ }^{15}$ ega mitteproletaarseks kuulutatud, olevat Hirschfeld olnud oma reisis pettunud, ning erinevalt oma tavalisest praktikast kirjeldas ajakirjanduses Nõukogude Liidu kogemust väga lakooniliselt. Homoseksuaalse kirjaniku Mihhail Kuzmini meenutuse kohaselt oli Hirschfeldi Leningradis toimunud loeng olnud „surmigav" (Healey 2001a: 138).

Sama aasta augustis kirjutas Päevaleht, et eeloleval sügisel või talvel, kui „pea ainukene oma ametikõrgusel seisev homoseksuaalküsimuste uurija" Hirschfeld on Põhja-Euroopa ringreisil, ootavad kohalikud arstid teadlast ka Tallinnasse. Nupukeses mainitakse veel Hirschfeldi hiljutisi Riia ja Nõukogude Liidu külastusi. Artikli lõpus võetakse tähelepanuväärselt teemaks homoseksuaalsete inimeste ja Hirschfeldi soojad suhted: „Dr. med. Hirschfeldti peale vaadatakse homoseksualistide ringkonnas kui õnnistaja peale, kuna ta neid kaitseb ja nendest täiel määral aru oskab

\footnotetext{
${ }^{14}$ Sama nupuke ilmus ka Järvamaas (Prof. M. Hirschfeld 1926b).

${ }^{15}$ 1917. aastal võimule tulnud bolševikud dekriminaliseerisid homoseksuaalsuse 1922. aastal. (See toimus siiski ainult Vene NFSV-s ja Ukraina NSV-s. Taga-Kaukaasia SFNV-s ja Kesk-Aasia liiduvabariikides jäi homoseksuaalsus kuriteoks või kriminaliseeriti juba 1920. aastail, nt Aserbaidžaanis 1923., Usbekistanis 1926. ja Türkmenistanis 1927. aastal (vt Healey 2001a: 158 jj, 2001b: 156).) Stalini võimuletuleku järel (1924) kriminaliseeriti homoseksuaalsed suhted taas 1933-1934, karistuseks määrati homoseksuaalsetele inimestele viis aastat kinnipidamisasutuses ja sunnitöö (vt nt Szulc 2017; Healey 2018).
} 
saada" (Dr. med. Magnus... 1926). Tõenäoliselt seda reisi Eestisse siiski ei toimunud, kuna mingeid muid jälgi peale selle ainsa eelteate pole õnnestunud ei ajakirjandusest ega kaasaegsete kirjutistest leida.

Hirschfeldi esimene, küllaltki suure eelkajastusega Eesti-reis toimus 1928. aastal, mil seksuoloog esines 22. ja 25. septembril loengutega Estonia kontserdisaalis. Võimalik, et samal käigul külastas lektor ka Tartut, kus toimus loeng Vanemuise teatris. ${ }^{16}$ 1928. aasta ettekannete kohta leidub ajakirjanduses eelinfot, kus tutvustatakse Hirschfeldi ja tema loengute võimalikke teemasid. Kaja teatab, et loengu teema on homoseksuaalsus, ning tutvustab Hirschfeldi kui teadlast, kes on „võidelnud seisukoha vastu, nagu oleks homoseksualism kuritegeline nähtus, mida tuleb seaduse järele karistada” (Prof. Hirschfeld... 1928). Päevaleht vihjab lugejale, et lektor on juba tuttav varasematest kõmuliste kohtuprotsesside kajastustest, ning tutvustab suguelu „väärnähtuste” uurija tegevust ja seisukohti populaarsel moel.

22.-25. septembrini esineb „Estoonia” kontsertsaalis loengutega Saksa maailmakuulus psühhopatoloog Magnus Hirschfeld, kelle nimi seotud paljude kõmuliste protsessidega - Haarmanni, ${ }^{17}$ Berliini õppurite Kranzi, Hilda Scheleri ja teiste ${ }^{18}$ - kus ta esinenud eksperdina.

Berliinis on prof. M. Hirschfeldil Tiergartenis eriline instituut, mille uksel Gooti kirjaga „Amori et dolori sacrum (Pühale armastusele ja kannatusele)", kus prof. M. Hirschfeld ühes oma kaaslastega teinud eluea kestel rohkesti väärtuslikke uurimusi suguelu väärnähtuste alal. Ta on üles seadnud väga julgeid teese, mis tugevat arvustust kui ka tunnustust on leidnud. Kõige rabavam on neist ta leitmotiiv, et kõik on hea, mis loomulik. Magnus Hirschfeld on laskunud sarnastesse suguelu küsimuste sügavustesse, kust paljud teda jälgides kohkunult tagasi põrkavad ja näevad neis sotsiaalse elu uuristust. Kuid prof. Hirschfeldi väited võidavad järjest enam poolehoidu. (Maailma kuulsaim... 1928)

Kuna loengud olid saksakeelsed, andis nende toimumisest Hirschfeldi tutvustava artikliga teada ka Tallinna saksakeelne ajaleht Revaler Bote (Vorträge von Prof... 1928). Hirschfeldi 1928. aasta Eesti loengute järel avaldatud referaate pole õnnestunud seni leida.

Seoses Hirschfeldi tulevase loenguga avaldab Uudisteleht varjunime Protens all tähelepanuväärse kirjutise pealkirjaga „Homoseksualistid meil ja mujal. Komblus langeb, homoseksualism levineb". Kirjutaja positsioon on ambivalentne: ühelt poolt

\footnotetext{
${ }^{16}$ Ainus seni leitud teade 1928. aastal Vanemuises toimunud Hirschfeldi loengu kohta on ilmunud 1931. aasta Dorpater Zeitungis, kus professor Alexander Brandt meenutab, kuidas ta oli Hirschfeldiga tutvunud pärast tema väljamüüdud ettekannet Vanemuises. Ettekande teemaks olevat olnud sooanomaaliad. Võimalik siiski, et autor eksib aastaarvuga ning räägib hoopis 1929. aastast. (Brandt 1931)

${ }^{17}$ Vihjatud on Eesti lehtedeski rohket tähelepanu leidnud Hannoveri sarimõrvarile Fritz Haarmannile (1879-1925), kes aastail 1918-1924 tappis ja tükeldas vähemalt 24 poissi ja noormeest vanuses 10-22. Eesti lehtedes avaldati ka Hirschfeldi kommentaare juhtumile.

${ }^{18}$ Vihjatud on eestikeelseski ajakirjanduses tähelepanu saanud 1927. aastal toimunud skandaalsele protsessile, kus Berliini teismeliste armukolmnurk viis traagiliste sündmusteni ning Hirschfeld oli kohtusse eksperdiks kutsutud.
} 
selgelt homofoobne, teisalt väljendab suurt huvi homoseksuaalsust puudutava suhtes. Nimelt selgub, et kirjutaja on osalenud 1921. aastal Berliinis Hirschfeldi loengul. Artikli alguses annabki autor ülevaate lektori põhiseisukohtadest ning kirjeldab seejärel stereotüüpsel moel Hirschfeldi kuulajaskonda.

Tallinn ootab haruldast külalist dr. Magnus Hirschfeldi Saksamaalt, kes siin tahab esineda loengutega seksuaalküsimuste üle. Dr. Hirschfeld on ilmakuulsusega teadlane seksuaalküsimuste alal. Muuseas näitab tema, et homoseksualism pole midagi lubamatut. See oli 1921 a. Berliinis, kui mina sattusin dr. Hirschfeldi poolt asutud ühingu avalikule koosolekule. Ühing võitles agaralt selle eest, et Saksa kriminaalseadusest kaoks homoseksualismi karistamise paragrahv. Koosolekul kõneles dr. Hirschfeld, kes kaunis kujukalt seletas, et armastuses mehe ja mehe vahel pole süütegu, mis nõuaks võimude vahelesegamist. Midagi komblusevastast siin pole. Mispärast loeb ennast riigivõim õigustatuks karistada meest, kes naisterahvast armastada ei taha, kuid kellel siiski on teatud tung armastuse järele? Saksa suurvaimud, nii kui Goethe ja Heine, olid ka homoseksualistid!... Vaatan ringi: Mõni pealtkuulajatest muigab salaja habemesse, kuid suurem osa kuulab tõsiselt kuulsa teadlase ettekannet. Silma torkasid mitmed noormehed, viimase moe järel riietud, suuremalt osalt mingitud ja puuderdud nägudega. Need teostavad naiste osa homoseksualistide juures. Veidrana meie vaatekohalt näib kõige selle juures asjaolu, et dr. Hirschfeld riigiteenistuses seisis kõrgel ametastmel. Küsitav on, kas nüüdse Saksamaa sõnavabadus kah nii kaugele ulatab, kui tol ajal. (Protens 1928)

Artikkel on tänuvärne queer-ajaloo allikas, kuna autor annab ülevaate talle teada olevatest homoseksuaalsete meeste kohtumispaikadest Tallinnas. Lisaks kirjeldatakse autori isiklikke kokkupuuteid homoseksuaalsete meestega Peterburis ja Moskvas (vt ka Kalkun 2018: 147-148).

1. ja 2. mail 1929. aastal toimus taas kaks ajakirjanduses rohkesti reklaamitud Hirschfeldi loengut Tallinnas Estonia kontserdisaalis. 3. mail samal aastal pidas Hirschfeld loengu ka Tartus Vanemuise teatris. ${ }^{19}$ Selgi aastal oli Hirschfeld eelnevalt külastanud Riiat, kus pidas loengud 27. ja 29. aprillil (Lipša 2016: 149). Päevaleht teatas lühiuudises, et Riia käsitööliste seltsi suur saal, mis mahutab 1500 inimest, oli välja müüdud (Prof. dr. med... 1929b). Riia loenguid külastas Pärnus sündinud baltisaksa kirjanik ja kolme avameelselt homoseksuaalsust käsitleva romaani autor Guido Hermann Eckardt (vt Lukas 2016), kes avaldas ajalehes Rigasche Rundschau loengutest põhjaliku referaadi (vt Eckardt 2010).

Hirschfeldi väidetavalt üsna paljude külastajatega Tallinna loengud kandsid pealkirju „Õigus armastuse peale” ja „Armastuse eksiteed. Seksualiteet ja kriminaliteet" ning nende sisu refereeriti põhjalikult ka ajakirjanduses (Suguelu päevaküsimusi 1929; Armastuse eksiteed 1929; Õigus armastuse peale 1929). Tallinna loengutele eelnes Estonia kontsertbüroo korraldatud reklaamikampaania, mis seisnes

\footnotetext{
${ }^{19}$ Vanemuises toimunud loengu teema oli „Armastuse eksiteed (Seksualiteet ja kriminaliteet)” (Prof. dr. med... 1929c). Vanemuise loengut külastas muuhulgas Johannes Semper, kes mainib seda möödaminnes seoses sellega, et Hirschfeld olevat nimetanud baltisakslast Hermann von Keyserlingi eestlaseks (Semper 1929: 724).
} 
ajalehekuulutustes ja pikemates eelteadetes, millest mõned sisaldasid Hirschfeldi fotot või šarži. ${ }^{20}$ Muuhulgas reklaamiti nii Tartus kui ka Tallinnas võimalust esitada lektorile küsimusi ning lubati, et Hirschfeld näitab ekraanilt „haigete” pilte (Prof. dr. med... 1929a; 1929c). Küllaltki põhjalikult avati eelteadetes ka loengus käsitletavad teemad.

Täna jõudis kuulus seksuaalteadlane prof. M. Hirschfeld Tallinna ja esineb kell 8 õhtul Estoonia kontsertsaalis huvitava loenguga teemi üle „Õigus armastuse peale”, milles ta tahab vastust anda rea tänapäeva põlevatele küsimustele ja selgitada populaarteaduslikult järgmiseid teese: Praegusaja seksuaalkõlbluse põhimõtted. Seksuaalne reform. Inimese 3 tungi. Hügieenilised ja kriminalistlised üleastumised. Sugukord ja seltskond. Naise iseseisvus. Seksuaalvabaduslik liikumine. Alaväärtusline seksualiteet. Nõuanne enne abiellumist. Sündimiste korraldus. Kas prostitutsioon on sallitav. Seksuaalselgitus ja seksuaalkasvatus. Lektor vastab publiku kirjalikkudele küsimustele. Estoonia kontsertbüroo (Millest kõneleb... 1929)

1. mail eelnes Estonias toimunud avalikule loengule kinnine loeng Tallinna suguhaiguste arstide seltsile (Õigus armastuse peale 1929). Avalik loeng „Õigus armastuse peale” olevat anonüümse refereerija sõnul rohkesti rahvast kokku toonud, kuna seksuaal- ja abieluküsimused alati huvi pakuvad. Esimeses loengus olevat Hirschfeld propageerinud seksuaalsust puudutavate küsimuste ja abieluinstitutsiooni ilmalikele ja teaduslikele alustele viimist. Seda kõike siiski „abielu kindlamale alusele” seadmiseks, mitte abielumoraali nõrgestamiseks ega abikaasade vastutustunde kaotamiseks. Hirschfeld, kelle teeneks oli esimeste abielunõuandlate avamine Saksamaal, soovitas soojalt ka Tallinnas luua „abielu nõuande kohti, millede ülesandeks on abiellu astujatele nõu anda ja abielus olijate vahel tekkinud arusaamatusi lahendada”. Samas leidis lektor, et abielulahutuse võimalus peaks muutuma lihtsamaks, eeskujuks tõi ta Nõukogude Venemaa, kus abielusid registreeritakse ja lahutatakse ilmalikult.

Teine Päevalehes ilmunud referaat oli põhjalikum ja detailsem. Näiteks avati enam naiste ja meeste võrdõiguslikkuse ning naise reproduktiivsust puudutavaid valikuid: „suguline rahuldumine on loomulik tarve, mehel ja naisel on ühevääriline õigus armastuse peale, abielu ainus ülesanne ei ole igal juhul lapsi soetada, seega [on] suguviljast kõrvalehoidmine lubatav" (Suguelu päevaküsimusi 1929). Loengus käsitleti Eestiski tol ajal aktuaalset abordi dekriminaliseerimise küsimust ning kritiseeriti tol ajal mitmel pool maailmas arutatavat „kurikalduvuslike” ja puuetega inimeste steriliseerimise poliitikat.

Teises Hirschfeldi loengus „Armastuse eksiteed” käsitleti homoseksuaalsust ning rõhutati, et kuna tegemist on kaasasündinud eelistusega, siis kohtumõistmisel tuleks käsitleda selliseid inimesi kui haigeid (Armastuse eksiteed 1929). Kuna Hirschfeldi teooria kohaselt olid homoseksuaalsed inimesed justkui „kolmas sugupool”, olid

\footnotetext{
${ }^{20}$ Tolleaegses ajakirjanduses polnud veel väga palju fotosid (vt Kurvits 2010), nii et Hirschfeldi visuaalsete kujutiste ilmumine oli seda märgilisem (vt nt Maailma kuulsaim... 1928; Suguelu küsimused... 1929; Dr. Magnus Hirschfeld 1929; Kas huliganid... 1930).
} 
tema teoorias tähtsal kohal ka n-ö soolise paleti vahevormid, st Hirschfeld tutvustas oma loengu illustratsioonides transsoolisusega seotud nähtusi. ${ }^{21}$

Edasi lektor peatus haiglaste nähete juures suguelus, mida selgitas valguspiltidega. Siin on peamiselt tegemist isikutega, milles mõlema soo omadused tulevad ilmsiks: naiselikud mehed ja mehelikud naised mitmesugustes väljendustes. Loodus, nagu mängides on sünnitanud haruldast segatüüpe nii hingeliselt kui ka väliste tunnuste järele. On kes tahavad olla naised ja ümberpöördult; nad kannatavad hingeliselt ja sageli oma elus esinevadki teisesoolisena, nagu see alles hiljuti ilmsiks tuli Inglismaal, kus naine oli mehe-riides ja oli ohvitseriks ja isegi abielus naisega. Ühes sugulise ebanormaalsusega ka nende inimeste vaimlised kalduvused erinevad ja sageli on kurikalduvuslikud. Sarnaste suguliste kurjategijate peale kohtumõistmisel tuleb vaadata kui haigete peale. (Armastuse eksiteed 1929)

Ilmselt seoses Eestis tegutsenud Alexander Lipschützi uurimustega kõneleb Hirschfeld siinsetele kuulajatele ka sugutungi seosest „sisemise sekretsiooniga ehk mahladest vabanemise tungiga" ning tutvustab tolleaegseid kõige radikaalsemaid katselise seksuaalsuse uurimise tulemusi, nt sugunärmete äralõikamise ja ümberistutamise tagajärgi, mis olevat loomkatsetes esile kutsunud muutusi kogu organismis (vt Healey 2001a: 134).

Hirschfeldi loengus sai esitada ka eelnevalt kirjalikult lektorile saadetud küsimusi, mida olevat olnudki „terve rida”. Ajalehed refereerivad ilmselt meelelahutuslikumat osa küsimustest ning pole teada, kas keegi esitas küsimusi, mis poleks mahtunud heteronormatiivsesse diskursusesse. Muuhulgas küsiti Hirschfeldi arvamust abordiõiguse ja n-ö sõprusabielu kohta. Paar küsimust olevat publikus naerukihina esile kutsunud (Õigus armastuse peale 1929).

Lektor andis mitmete huvitavate küsimuste peale vastust. Keegi küsis: millega seletatav, et ta peab oma mehest lugu, aga ei või sallida füüsilist puudutamist. Vastus oli, et abielus paljast lugupidamisest ei jätku, vaid peab olema erootilist külgetõmbavust. Teine küsis, kas alastiolek on kirgesid äratav ja üks teine tahtis kuulda praegu moes, kõrgelt näha olevatest naiste säärtest. Vastus - alasti olek ei ole igal juhul kirgi äratav, vaid on inimesi, kes alastiolekut üldse ei salli; teised tunnevad kirge otse paksult riietes olijatest. Palju teeb harjumus. Alasti võib alul mõjuda, pärast see muutub päris harilikuks. Berliinis harrastatakse suuresti alasti kultuuri (teatud ringides) ja seal pole midagi erilist. Lõpuks ütleb lektor, et uus seksuaaleetika tahab paremust suguelus; ta toimib, täiesti tundes suurt vastutust oma õpetuse eest. (Suguelu päevaküsimusi 1929)

Hirschfeldi nimi figureerib aeg-ajalt Eesti ajakirjanduses ka pärast 1929. aasta loenguid. Seksuoloogi seisukohti refereeritakse ekspertarvamusena eriti meelelahutuslikus kontekstis, kui kõneldakse mingil teemal, mis puudutab kuidagi inimese seksuaalsust (nt artikkel seksuaalkuritegudest (Kas huliganid... 1930), vamp-

${ }^{21}$ Hirschfeldi mainiti neil aastail Eesti ajalehtedes transseksuaalsusega seotud ajaloolisi isikuid puudutavates lugudes, nt Soovõltsijad 1928; Soovõltsimised 1928; Mehed naise... 1935. 
naistest (Naised, kes... 1935) või õnnetust armastusest (Õnnetu armastus 1936)). Hirschfeldi teoseid reklaamivad Eesti raamatupoodide ajalehereklaamid ning 1930. aastail jõuab Hirschfeldi osalusel valminud tummfilm „Das Recht auf Liebe” („Õigus armastusele”) Eesti kinodesse. Kuigi film käsitleb tõsist küsimust, kas maailmasõja haavadest impotendiks jäänud mehel on õigus abielluda, reklaamitakse filmi Eestis pelgalt meelelahutuslikuna (Maailma kõmulisema... 1930).

Seoses Hirschfeldi raamatuga „Die Sittengeschichte des Weltkrieges” („Maailmasõja moraaliajalugu”, 1930) tõuseb väike inetu skandaal veel 1930. aastate alguses baltisaksa lehtedes. Nimelt avaldas Evangelisch-Lutherisches Kirchenblatt für die deutschen Gemeinden Lettlands selgelt antisemiitliku kriitika Hirschfeldi edukate raamatuprojektide kohta, mis ka Dorpater Zeitungis kommentaarideta ära trükiti (Ausland 1931). „Magnus Hirschfeldt kuulub nende saksa juutide hulka, kes näiliselt tõde ja valgustust teenivad, aga tegelikult külmaverelise vastutustundetusega teaduslikkuse kaitsemantli all häbitunnet ja kombeid veelgi lammutavad ning oma ligimeste lõbujanu pealt suurepärast äri teevad," tsiteerib Tartu leht. Sama tsitaadi ja hoiatuse toob oma kirjutises ära ka Tartu ülikooli professor Alexander Brandt, kes seletab esmalt, kuidas ta olevat Hirschfeldiga pärast Vanemuise loengut tutvunud ning kinkinud talle oma raamatu „Sexualität. Eine biologische Studie” („Seksuaalsus. Bioloogiline uurimus", 1925), hiljem järele saatnud ka oma uusima raamatu „Feminismus. Seine Begründung und Folgen” („Feminism. Põhjendus ja tagajärjed”, 1929). Brandt polevat Hirschfeldilt oma viimasele raamatule sobivat arvustust aga saanud ning nõustub evangeelse lehega, et Hirschfeld on kahepalgeline (Brandt 1931).

1935. aastal, kui natsionaalsotsialistid olid Hirschfeldi seksuaalteaduste instituudi sulgenud ja Berliinis ooperiteatri ees suure osa instituudi raamatukogust põletanud, avaldas Eestis ilmuv saksakeelne leht Deutsche Zeitung intervjuu Adolf Ehrtiga, kes oli Saksa poliitilise kõrgkooli antimarksistliku seminari juhataja. Seminari eesmärgiks oli propagandistlik ja teaduslik võitlus kommunismi vastu ning see uus asutus paiknes ajaloo tähelepanuväärse paradoksina, nagu ajakirjanik teravmeelselt kirjutas, kuulsa „seksuaalkommunisti” dr Hirschfeldi endise valgustusinstituudi ruumes (Aus der Arbeit... 1935).

\section{Kokkuvõtteks}

XX sajandi alguses Saksamaal toimunud homoseksuaalsete inimestega seotud skandaalide jõudmine Eesti lehtedesse peegeldab ühelt poolt kujukalt homoseksuaalsuse sõnastamise raskusi, aga teisalt ka seda, kuidas järjest nobedamini tõlgiti eesti lugejale mõistetavaks Euroopas toimunud diskussioonid ja mõttevoolud. Kui Alfred Kruppi juhtumi juures läks veel nii mõndagi tõlkes kaduma (või jäi tsensori kääride vahele), siis Eulenburgi skandaali pikaajaline kajastamine Eesti lehtedes muudab ilmselt midagi palju rohkemat kui tavalise välismaise kõmu-uudise vahendamine. Eesti ajaloos jääb Eulenburgi skandaali ja Magnus Hirschfeldi Estonia ja Vanemuise loengute vahele tõeliselt sündmusterikas periood. See, et 1920. aastate lõpul võis 
minna Estoniasse või Vanemuisesse kuulama Hirschfeldi ning lugeda eestikeelses ajalehes refereeritud moodsaid mõtteid inimese seksuaalsuse kohta, on ilmselt vahetult seotud ka nende esimeste konarlike katsetega sõnastada homoseksuaalsust.

Koos välismaiste kõmu-uudistega toitis ajakirjandus muidugi ka moodsa inimese hirme ja ihasid. Lugejate ette jõudsid linnalegendid ja ohtlikud stereotüübid, aga ka õudused ning intiimsed seksuaalsfääri puudutavad asjad. Homoseksuaalsuse sõnastamine toimus sageli pahelises, kõmulises või vaenulikus kontekstis. Välismaine homoseksuaal ilmus eesti lugejale tõeliselt võõrana: kui teolt tabatud kõrgest seisusest kõlvatu lõbutseja või hull ja ohtlik kurjategija. Siiski jagati koos Magnus Hirschfeldi sõna levitamisega ka empaatilisemat vaadet sellele „tõule”. Ilmselt pidi mõni lugeja ka oma lähedases ära tundma selle, kellest lehes kirjutati. Võimalik, et see, et Eesti Vabariigis vastu võetud kriminaalseadustikus polnud homoseksuaalsus kriminaliseeritud, ${ }^{22}$ on seotud diskussioonidega, mida oli lehtedes peetud juba Eulenburgi skandaalist alates.

Tänan kasulike näpunäidete eest Rebeka Põldsamit ja Jaan Unduskit. Artikli valmimist on toetanud Eesti Teadusagentuuri uurimisprojekt IUT22-4 „Folkloor kultuurilise kommunikatsiooni protsessis: ideoloogiad ja kogukonnad", Euroopa Liit Euroopa Regionaalarengu Fondi kaudu (Eesti-uuringute Tippkeskus) ning KONE fondi ja Helsingi ülikooli uurimisprojekt „Omistajuus, kieli ja kulttuuriperintö - Kansanrunousideologiat Suomen, Karjalan tasavallan ja Viron alueilla".

\section{KIRJANDUS}

Armastuse eksiteed. Prof. dr. med. Magnus Hirschfeldi teine loeng. - Päevaleht 4. V 1929, nr 119, lk 4.

Aus der Arbeit der „AntiKomintern”. Ein Interview mit ihrem Leiter Dr. Adolf Ehrt. (Von unserem Berliner Korrespondenten.) Berlin, im November. - Deutsche Zeitung 4. XII $1935, \mathrm{lk} 1$.

Ausland. Deutschland. Eine Sittengeschichte des Weltkrieges? - Dorpater Zeitung 15. I 1931, lk 3.

Bauer, Heike 2017. The Hirschfeld Archives: Violence, Death, and Modern Queer Culture. Philadelphia: Temple University Press.

Brandt, Alexander 1931. Zur Sittengeschichte. - Dorpater Zeitung 26. I, lk 2.

Cameron, Deborah; Kulick, Don 2003. Language and Sexuality. New York: Cambridge University Press.

Domeier, Norman 2015a. Die deutsche Homosexuellenbewegung im Kaiserreich und ihre Niederlage im Eulenburg-Skandal. - Gewinner und Verlierer: Beiträge zur Geschichte

\footnotetext{
${ }^{22}$ Eesti Vabariigis vastu võetud karistusseadustiku kohaselt polnud täiskasvanute vahel mõlema poole nõusolekul toimunud homoseksuaalsed seksuaalaktid kriminaliseeritud. Eesti Vabariigi kriminaalseadustik võeti vastu 26. märtsil 1929. aastal ning hakkas reaalselt kehtima 1. veebruaril 1935. aastal pärast distsiplinaarseadustiku ja vangistusseadustiku vastuvõtmist ning muudatuste tegemist tollases kriminaalprotsessi korralduses.
} 
der Homosexualität in Deutschland im 20. Jahrhundert. (Hirschfeld-Lectures 7.) Göttingen: Wallstein Verlag, lk 13-26.

Domeier, Norman 2015b. The Eulenburg Affair. A Cultural History of Politics in the German Empire. New York: Camden House.

Dr. Magnus Hirschfeld. - Kaja 15. IX 1929, nr 218, lk 2.

Dr. med. Magnus Hirschfeldt Tallinna? - Päevaleht 29. VIII 1926, nr 233, lk 2.

Eckardt, G. H. 2010. Über zwei Vorträge von Magnus Hirschfeld. Riga 27. und 29. Aprill 1929. - Fritz Geron Pernauhm. Die Infamen. Hamburg: Männerschwarm, lk 237-241.

Foucault, Michel 2005. Seksuaalsuse ajalugu. 1, Teadmistahe. Tlk Indrek Koff. Tallinn: Valgus.

Halperin, David M. 2002. How to Do the History of Homosexuality. Chicago-London: University of Chicago Press.

Healey, Dan 2001a. Homosexual Desire in Revolutionary Russia. The Regulation of Sexual and Gender Dissent. Chicago-London: The University of Chicago Press.

Healey, Dan 2001b. Masculine purity and 'gentlemen's mischief'. Sexual exchange and prostitution between Russian men, 1861-1941. - Slavic Review, kd 60, nr 2 (suvi), lk 233-265.

Healey, Dan 2018. Russian Homophobia from Stalin to Sochi. London-Oxford-New YorkNew Delhi-Sydney: Bloomsbury Academic.

Hennoste, Tiit; Kurvits, Roosmarii 2019. Eesti ajakirjanduse 100 aastat. Matsilehest võrguleheni. Tallinn: Post Factum.

Hirschfeld, Magnus 1920. Die Homosexualität des Mannes und des Weibes. Mit einem Namen-, Länder-, Orts- und Sachregister. Berlin: Marcus.

Hunntus, G. 1920. Oscar Wilde ja tema „Salome”. - Postimees 9. II, nr 34, lk 1.

Järjejutt $1915=\ldots$ keisrikoja lähedal seisvad isikud olivad. - Uusleht 23. IV, lk 442.

Kaheksas rahvusvaheline karskuse-kongress Wienis. - Postimees 1. V 1901, nr 96, lk 1.

Kalkun, Andreas 2010a. Naiselikkus, mehelikkus ja seksuaalsus talupojakultuuris. Siin kasvab priskelt eesti neiu ja sirgub eesti mehele? - Kapiuksed valla. Arutlusi homo-, bi- ja transseksuaalsusest. Koost Brigitta Davidjants. Tallinn: Avatud Eesti Fond, MTÜ Eesti Gei Noored, lk 12-22.

Kalkun, Andreas 2010b. Work first and love will follow. Division of labor and male beauty in Estonian folk culture. - AAFAGC. Applied Art for a Gay Club. Toim Jaanus Samma, Alo Paistik. Tallinn-Paris, lk 51-62.

Kalkun, Andreas 2016. Feodor Vanahundi ropud naljad. Erootiline imperatiiv, poeesia ja tabustatud seksuaalkäitumise viisid. - Tartu Ülikooli Lõuna-Eesti keele- ja kultuuriuuringute keskuse aastaraamat XV-XVI. Setumaa kogumik 7. Pühendusteos Paul Hagule. Toim Helen Kästik, Eva Saar. Tartu-Värska: Tartu Ülikooli Kirjastus, lk 118-137.

Kalkun, Andreas 2017. Talurahva seksuaalelu mõistatusi. - Müürileht 21. III. https:// www. muurileht.ee/talurahva-seksuaalelu-moistatusi/ (14. VI 2018).

Kalkun, Andreas 2018. Ajalugu, mida polnud? Homoseksuaalse iha jäljed kolmes kohtuasjas. - Mäetagused, nr 71, lk 143-174.

Kalkun, Andreas; Sarv, Mari 2014. Seks ja poeetika: regilaulu peidus pool. - Vikerkaar, nr 4-5, lk 91-108. 
Kas huliganid või seksuaalhaiged? Pimedate tänavate hirm. Kallaletungid naistele. Ebaloomulikud kalduvused ja kired. Huligaansusest roimani. Käesoleval aastal seksuaalteaduse uurijate konverents - kas ka meilt läheb esindaja? - Rahvaleht 16. I 1930, nr 7, lk 4.

Kurvits, Roosmarii 2010. Eesti ajalehtede välimus 1806-2005. Tartu Ülikooli sotsiaal- ja haridusteaduskond, ajakirjanduse ja kommunikatsiooni instituut. Tartu: Tartu Ülikooli Kirjastus.

Lipschütz, Alexander 1921. Sugunäärmete sisesekretsioonist. - Sõjaväe arstide teadusliste koosolekute protokollid. Nr. 3. Sõjaväe Tervishoiu Valitsus. Tallinn: Sõjaväe trükikoda, lk 61-64.

Lipschütz, Aleksander 1923. Seksuaal- ehk suguline küsimus ja suguline kasvatus. Mis on seksuaalküsimus? - Päevaleht 16. II, nr 45, lk 2.

Lipša, Ineta 2016. Communication of non-normative sexuality in inter-war Latvia (1920s and 1930s). - Queer stories of Europe. Toim Kārlis Vērdiņš, Jānis Ozoliņš. Newcastle upon Tyne, UK: Cambridge Scholars Publishing, lk 144-173.

Lipša, Ineta 2018. LGBTI People in Latvia: A History of the Past 100 Years. Riga: Association of LGBT and their friends Mozaika.

Lukas, Liina 2016. Literary Queer Mésalliances in Riga around 1900. - Queer stories of Europe. Toim Kārlis Vērdiņš, Jānis Ozoliņš. Newcastle upon Tyne, UK: Cambridge Scholars Publishing, lk 110-122.

Löfström, Jan 1999. Sukupuoliero agraarikulttuurissa. „Se nyt vaan on semmonen”. Helsinki: SKS.

Löfström, Jan 2015. Miten päätellä, onko hiljaisuus vaikenemista? „Homoseksuaalisuus” agraarikulttuurin perinneaineistoissa. - Salattu, hävetty, vaiettu. Miten tutkia piilossa olevia ilmiöitä. Toim Antti Häkkinen, Mikko Salasuo. Tampere: Vastapaino.

Maailma kuulsaim psühhopatoloog Tallinna. Loengud „Estoonia” kontsertsaalis. - Päevaleht 11. IX 1928, nr 247, lk 6.

Maailma kõmulisema suurfilmi esietendus. - Pärnu Päevaleht 30. IV 1930, lk 4.

Maailma riikidest. - Ristirahva Pühhapäevaleht 1. XII 1902, lk 6-7.

Mancini, Elena 2010. Magnus Hirschfeld and the Quest for Sexual Freedom. A History of the First International Sexual Freedom Movement. (Critical Studies in Gender, Sexuality, and Culture.) Palgrave Macmillan US.

Mehed naise, naised mehe rüüs. Vastassugupoole riietuse eelistajad. On see haigus või harjumus? Kuninganna Kristine ja Orleani neitsi olid transveriidid. - Tallinna Post 31. V $1935, \mathrm{lk} 3$.

Millest kõneleb täna „Estoonia" kontsertsaalis prof. dr. med. Magnus Hirschfeld. - Päevaleht 1. V 1929, nr 116, lk 6.

Moltke-Hardeni protsess Saksamaal. - Päevaleht 17. X 1907, nr 236, lk 2.

Naised, kes ei tohi abielluda. Vamptüüpide saladus. - Film ja Elu 21. VI 1935, nr 24, lk 1.

Nende elu, armastus ja kannatused. Saatuse löögid inimeste peal. Heade kavatsuste halvad tagajärjed. - Rahvaleht 7. III 1929, lk 5-6.

Politika ringvaade 1907a = Politika ringvaade ja väljamaa sõnumed. - Koit 19. X, lk 2.

Politika ringvaade 1907b = Politika ringvaade ja väljamaa sõnumed. - Koit 23. X, lk 2.

Politika ringvaade 1907c = Politika ringvaade ja väljamaa sõnumed. - Koit 30. X, lk 2.

Politika ringvaade 1908 = Politika ringvaade ja väljamaa sõnumed. - Koit 6. V, lk 1. 
Politika ringvaatus $1902 a$ = Politika ringvaatus ja väljamaa sõnumid. Saksamaa. - Postimees 15. XI, nr 255, lk 2 .

Politika ringvaatus 1902b = Politika ringvaatus ja väljamaa sõnumid. Saksamaalt. - Postimees 18. XI, nr 257, lk 2.

Prof. A. Lipschütz Tallinna jõudnud. - Päevaleht 13. VIII 1919, nr 170, lk 3.

Prof. dr. med. 1929a = Prof. dr. med. Magnus Hirschfeldt Tallinnas. - Kaja 28. IV, nr 98, lk 10.

Prof. dr. med. 1929b = Prof. dr. med. Magnus Hirschfeldti loenguks. - Päevaleht 1. V, nr 116, lk 7 .

Prof. dr. med. 1929c = Prof. dr. med. Magnus Hirschfeldt Tartus. - Postimees 3. V, nr 118, lk 1.

Prof. Hirschfeld tuleb Tallinna. - Kaja 12. IX 1928, nr 213, lk 4.

Prof. M. Hirschfeld 1926a = Prof. M. Hirschfeld abortidest. Saksamaal 800.000 aborti aastas. - Sakala 22. V, nr 61, lk 3.

Prof. M. Hirschfeld 1926b = Prof. M. Hirschfeld abortidest. Saksamaal 800.000 aborti aastas. - Järvamaa 4. VI, lk 3.

Protens 1928. Homoseksualistid meil ja mujal. Komblus langeb, homoseksualism levineb. Uudisleht 19. IX, nr 70, lk 5.

Seltsimees Prof. A. Lipschütz Tallinna jõudnud. - Sotsialdemokrat 13. VIII 1919, lk 3.

Semper, Johannes 1929. Muljeid PEN-klubide rahvusvahelisest kongressist Viinis. - Looming, nr 6, lk 721-736.

Soovõltsijad. Kui mehed tahvad olla naised, ja ümberpöördult. - Postimees 13. II 1928, nr 43, lk 5.

Soovõltsimised. Mehed, kes tahavad olla naised, ja naised, kes tahavad olla mehed. Päevaleht 6. II 1928, nr 36, lk 3.

Szulc, Lukasz 2017. Transnational Homosexuals in Communist Poland. Cross-Border Flows in Gay and Lesbian Magazines. New York: Palgrave Macmillan.

Suguelu küsimused päevakorral. Kuulus suguelu uurija dr. Magnus Hirschfeld tuleb Tallinna. - Kaja 24. IV 1929, nr 94, lk 9.

Suguelu päevaküsimusi. Abielu soodsamaid vorme. Suguviljast hoidumine ei ole kuritegu. Nooruse tutvustamine suguelu küsimustega. Õigus armastuseks ja enesepiiramine. Eesti abordiseadus ajakohane kompromiss. - Päevaleht 3. V 1929, nr 118, lk 4.

Taavetti, Riikka 2018. Queer Politics of Memory. Undisciplined Sexualities as Glimpses and Fragments in Finnish and Estonian Parts. University of Helsinki, Faculty of Social Sciences.

Veispak, Teet 1991. Homosexuality in Estonia in the 20th century. Ideological and juridical aspects. - Sexual Minorities and Society. The Changing Attitudes Toward Homosexuality in 20th Century Europe. Papers Presented to the International Conference in Tallinn May 28-30, 1990. Toim Udo Parikas, T. Veispak. Tallinn: Eesti Teaduste Akadeemia ajaloo instituut, lk 105-114.

Vērdiṇš, Kārlis 2016. The Harden-Eulenburg Affair and the Latvian Image of Germans. Queer stories of Europe. Toim K. Vērdiņš, Jānis Ozoliņš. Newcastle upon Tyne, UK: Cambridge Scholars Publishing, lk 123-133.

Vorträge von Prof. Dr. Magnus Hirschfeld. Berlin. - Revaler Bote, 14. IX 1929, $1 \mathrm{k} 7$.

Väljamaa 1902a = Väljamaa. Saksamaa. - Olevik 19. XI, lk 10-11. 
Väljamaa 1902b = Väljamaa. Saksamaa. Praeguse aja „heategija” ja „isamaalane”. - Olevik 10. XII, lk 10-12.

Väljamaalt 1902 = Väljamaalt. Saksamaalt. - Uus Aeg 14. XI, lk 3.

Väljamaalt 1907a = Väljamaalt. - Ristirahva Pühapäevalehe Sõnumitooja 19. X, lk 4-5.

Väljamaalt 1907b = Väljamaalt. Inetu protsess Saksamaal. - Päevaleht 16. X, nr 235, lk 2.

Väljamaalt 1908 = Väljamaalt. Saksamaalt. Skandal. - Meie Elu 26. IV, lk 2.

Vürst Eulenburgi protsess. - Isamaa 28. VI 1908, lk 2.

Weil, A. (toim) 1922. Sexualreform und Sexualwissenschaft. Vorträge gehalten auf der 1. Internationalen Tagung für Sexualreform auf sexualwissenschaftlicher Grundlage in Berlin. Stuttgart: Püttmann.

Õigus armastuse peale. Alasti olemise kultuur Saksamaal arendamisel. Prof. Magnus Hirschfeldi loengult. - Kaja 3. V 1929, nr 102, lk 8.

Õnnetu armastus. Pilk inimhinge kulisside taha. - Film ja Elu 24. VII 1936, nr 26, lk 1.

Ülikooli teated. Rahvusvaheline seksuaal-reformi kongress, kuhu ka Tartu ülikooli esitaja kutsutakse. - Päevaleht 12. VIII 1921, nr 211, lk 5.

Andreas Kalkun (snd 1977), PhD, Eesti Kirjandusmuuseumi Eesti Rahvaluule Arhiivi teadur (Vanemuise 42, Tartu 51003), andreas@folklore.ee

\section{Attempts to find words for homosexualism: the Eulenburg scandal and the lectures of Magnus Hirschfeld in the early $20^{\text {th }}$ century Estonian press}

Keywords: Estonian LGBTI history, Magnus Hirschfeld, Eulenburg affair

Towards the end of the $19^{\text {th }}$ century Estonian journalism developed a more global grasp, while the traditional educational and instructive texts were increasingly accompanied by foreign news and entertainment. First, the article acquaints the readers with the representations of the Eulenburg scandal in Germany in the Estonian press of the early $20^{\text {th }}$ century, then proceeds to the local Estonian coverage of Magnus Hirschfeld's lectures held in the late 1920s, who campaigned for the decriminalisation of homosexualism. Both the Eulenburg scandal and Hirschfeld's visits made Estonian journalists to articulate the homosexual desire and contextualise it for the reader. For both cases, the coverage is ambivalent, providing, on the one hand, a neutral explanation or a pedagogical conceptualisation of homosexuality, yet also revealing homophobia and prejudice. At the same time, however, those early formulations are absolutely significant, introducing (male) homosexuality among the topics debatable in Estonian-language public space.

Andreas Kalkun (b. 1977), PhD, Estonian Literary Museum, Estonian Folklore Archives, Researcher (Vanemuise 42, Tartu 51003), andreas@folklore.ee 